\title{
Landslide susceptibility mapping using AHP and GIS weighted overlay method: a case study from Ljig, Serbia
}

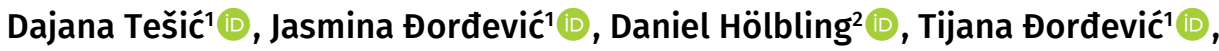

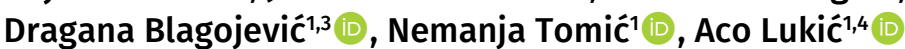 \\ ${ }^{1}$ University of Novi Sad, Faculty of Sciences, Department of Geography, Tourism and Hotel Management \\ ${ }^{2}$ University of Salzburg, Department of Geoinformatics - Z_GIS \\ ${ }^{3}$ BioSense Institute - the Research and Development Institute for Information Technologies in Biosystems, Novi Sad \\ ${ }^{4}$ Charles University, Prague, Faculty of Science, Department of Demography and Geodemography
}

Keywords:
Landslides,
Analytic hierarchy
process (AHP),
weighted overlay method,
susceptibility mapping,
GIS,
Ljig.

\begin{abstract}
Landslides are one of the natural hazards that occur frequently in Serbia, causing huge loss of property every year, especially after heavy rainfall events. Due to the geological condition, rapid development activities and other inherent natural conditions, the Ljig municipality has been exposed to landslide hazards. Therefore, the present study concentrates on landslide susceptibility (LS) analysis in this area using the analytical hierarchy process (AHP) and geographic information system (GIS) weighted overlay method. The causative factors considered for the study (slope, geology, pedology, distance from roads, distance from river network, land cover and rainfall) were graded and the result was a map showing areas divided into five classes based on the possibility of landslide occurrence (from very low to very high). According to the landslide susceptibility area map, about $42 \%$ of the study area falls into high and very high susceptibility zones and approximately $44 \%$ of the area has medium susceptibility for landslide events. The results of this study can be a valuable input for slope management, land use planning and disaster management planning by the responsible authorities.
\end{abstract}

\section{Introduction}

In geomorphology, a "landslide" is the movement of a mass of rock, debris or earth down a slope under the influence of gravity (Cruden and Varnes, 1996). In a broader sense, landslides are downward movements of rock, debris or earth masses, usually developed along predefined planar discontinuities. These are called slip-surfaces (simple planar or higher order complex surfaces), which propagate throughout the mass and separate intact bedrock material from the moved material above. Other elements of a landslide include crown and head, separated by a scarp; main body, channeled by flanks; foot, terminated by a toe; depletion zone capturing upper and accumulation zone capturing lower portions of a landslide. Landslides can drastically vary in size and area, as well as in other characteristics. They can develop in natural or engineered/constructed slopes. A large number of active landslides today are caused by inappropriate construction works and land cultivation (Marjanović, 2013). Consequently, they have been studied in various scientific branches ranging from Geology and Geomorphology to Geological, Geotechnical and Civil Engineering (Lee and Jones, 2004; Bell, 2007). Relative to other natural disasters, the International Disaster Database (EM-DAT) suggests that landslides account for $4.9 \%$ of all natural disaster events and 1.3\% of all natural hazard fatalities between 1990 and 2015 (Ali et al., 2019). However, the dedicated global landslide databases indicate that global multi-peril databases underestimate the impact of landslides on society. Landslide susceptibility stands for the spatial distribution and magnitude estimation 
of landslides which exist or may potentially occur over an area. It could also be treated as a pure spatial probability of landslide occurrence (Fell et al., 2008). Landslide hazard stands for a probability of landslide occurrence over an area within a given time period (temporal probability). It could be regarded as a temporal extension of susceptibility. It is sometimes confused with susceptibility, but it is sufficient to notice its temporal dimension to make a distinction (Lee and Jones, 2004). Undeniably, landslide hazard awareness reached considerable quota in recent years. It involves not just the general population, but the academic circles and political officials, as well. Google's insight for search indicates a considerable average rise in interest for keywords such as landslide, debris flow, landslide hazard and susceptibility. The interest is particularly high right after the events that had caused considerable damage to society and that have been followed-up by media. Consequently, interest is the highest in the affected areas (Marjanović, 2013). The Republic of Serbia has suffered huge economic losses over the last decades due to natural disasters. In Serbia, 30-35\% of the territory is landslide-prone (Milošević et al., 2006). The occurrence of landslide events has remarkably increased in this region due to climate variation, intense rainfalls and increased population pressure. External or internal factors, e.g. slope steepening, removal of support from slope, inherently weak material, etc. may trigger landslide events (Ali et al., 2019). The rainfall that triggered numerous landslides in 2006 and 2014 caused extensive damage to housing, infrastructure, agriculture, etc. According to Milošević et al. (2006), due to its geological structure and terrain morphology, central Serbia is susceptible to the formation of landslides with even small changes in geometry or burdening of unstable slopes. Registered landslide areas in the study area are small in size and are usually the consequence of human activities, most often following cuts for road routes. The territory of the Ljig municipality is in great part affected by landslide processes (Milošević et al., 2006). Van Westen et al. (2003) and Galli et al. (2008) considered and examined the relationship between geomorphological factors and the appearance of landslides. Awawdeh et al. (2018) developed a landslide susceptibility map (LSM) along the Jerash-Amman highway in Jordan using geographical information systems (GIS) and weighted overlay method. A few studies investigated landslides in the municipality of Ljig. Milošević et al. (2006) presented the locations of frequent occurrences of landslide processes, while Đorđević (2006) examined and evaluated natural environmental factors influencing the development of the Ljig municipality. Besides, GIS was used in the spatial analysis of the landslide susceptibility of slopes and described thoroughly by Carrara et al. (1995).

The main objective of this study is the use of GIS and Remote Sensing to produce a landslide susceptibility map of the Ljig municipality. The increasing popularity of GIS has led to many studies, predominantly using indirect susceptibility mapping approaches. As a consequence, fewer investigations use GIS in combination with a heuristic approach, either geomorphological mapping or analytical hierarchic process (AHP). Accordingly, this study displays a landslide susceptibility assessment method based on GIS technology combined with an AHP-weighted information content method. This area is prone to landslides and has therefore been chosen as the subject of this study. The aim of this research is to give an analysis and to try to locate the potential future appearances of the landslides and with this kind of approach find possible solutions and affect minimizing the losses.

\section{Study area, data and methods}

\subsection{Study area}

The municipality of Ljig is located in the central part of Serbia (Fig.1). With an area of $278.84 \mathrm{~km} 2$ it is neighboring two entities, one belonging to šumadija and the other to northwestern central Serbia (Spatial plan of the municipality of Ljig, 2008). The boundary between these two areas is the Ljig River, which flows through the western and northwestern areas of the municipality. The southern part of the municipality is situated on the main ridge of Suvobor mountain. The mountainous area covers the southern and eastern parts of the study area and flatlands (up to $200 \mathrm{~m}$ elevation) cover $23.1 \%$ of the total territory of the Ljig municipality. The analysis of the slope angles revealed that flatland (less than $3^{\circ}$ ) occupies $15 \%$ or $44 \mathrm{~km} 2$, and the difference of $8 \%$ refers to valley sides that are at lower elevations than $200 \mathrm{~m}$, but they are at considerable slopes (over 30 and most often 5-80), thus, they cannot be classified as plains. The area varies in elevation from about $121 \mathrm{~m}$ near the settlement Latković in the northern part, to $848 \mathrm{~m}$ in the southern part (Radanović, 2010). The mean annual temperature within the study area for the last 30 years is about $11^{\circ} \mathrm{C}$ in the lowest parts and about $9^{\circ} \mathrm{C}$ in the mountainous parts. During the growing season, which lasts from late March to late October, the mean temperature ranges between $14^{\circ} \mathrm{C}$ at Rajac to $17-18^{\circ} \mathrm{C}$ in the lowest parts of the municipality. The average annual rainfall for this area is $810 \mathrm{~mm} /$ year, but it varies from $650 \mathrm{~mm} /$ year in the northern parts to $1000 \mathrm{~mm} /$ year in the mountainous area. The highest rainfall is in the period May-July and the 
lowest in January-March (Spatial plan of the municipality of Ljig, 2008).

According to the last Population Census (2011) the municipality had about 12,000 inhabitants. The population lives in 28 settlements, of which the only urban settlement is Ljig, which is also the largest settlement with 3226 inhabitants. The municipality is predominantly agricultural with a $45 \%$ share of cultivated land (Municipalities and regions of the Republic of Serbia 2018, 2019).

In addition to the national road $\mathrm{M} 22$ and the regional road network, there is also a highway, "Miloš Veliki", which was completed in 2016, that also passes through the municipality.

\subsection{Data}

The starting point for performing a GIS-based landslide susceptibility analysis is the collection of the data considered to influence the occurrence of landslides. The selection of causal factors differs depending on the scale of analysis, the characteristics of the study area, the landslide type and the failure mechanisms (Van Westen et al. 2008). In this study, for assessing and mapping the landslide susceptibility in the Ljig municipality, the following predisposing factors were selected: lithology, land cover, hydrological factors and morphometric factors, i.e. slope angle and aspect. For each of these layers, the incidence of landslides in their classes was evaluated (Pellicani et al., 2017). The main data required for landslide susceptibility and risk assessment in this study were collected from various sources and are presented in Table 1.

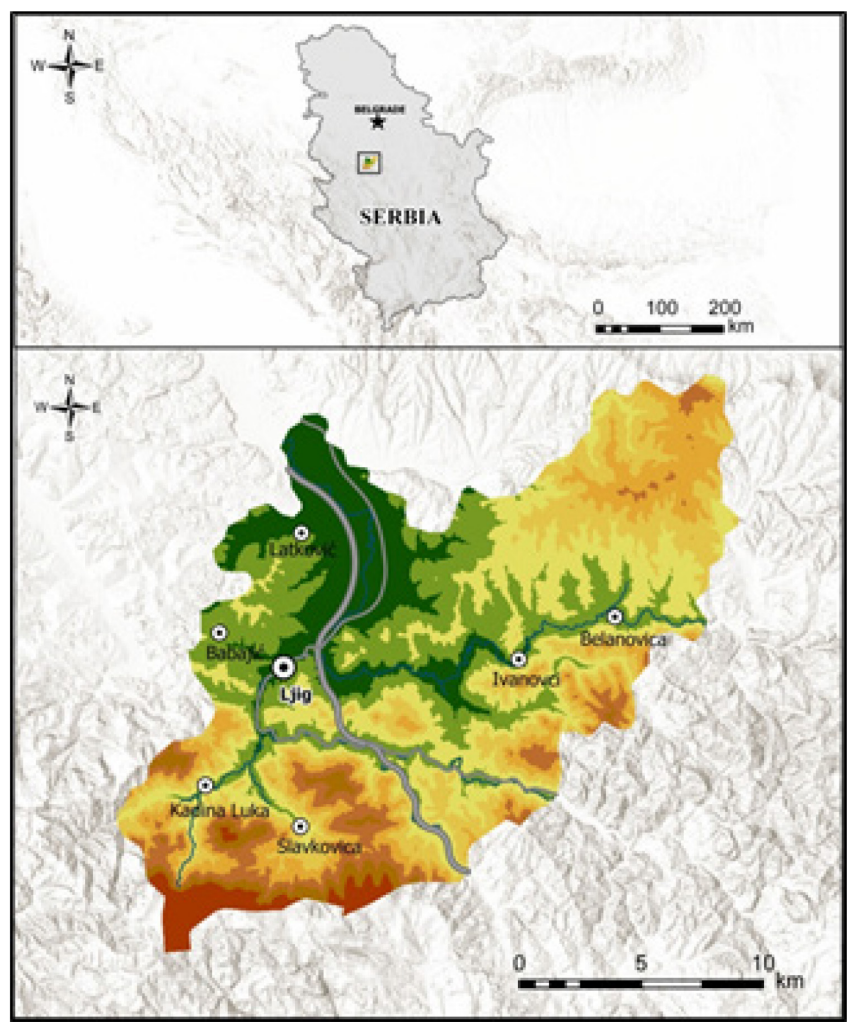

Figure 1. Location of the study area

The first step was the creation of the derivatives from the ASTER global digital elevation model (DEM, $30 \mathrm{~m}$ resolution). This included the calculation of the slope angle and the aspect in ArcGIS Pro 2.5 software. A digital relief model was used to generate the slope layer and slope expositions (Abrams, 2016). It is known that "as the slope increases, the shear stress on the slope increases, and the probability of landslide occurrence also increases" (He et al., 2019, p. 15).

Table 1. Sources of data used for the study

\begin{tabular}{|c|c|c|}
\hline Data & Description & Source \\
\hline Landsat $80 \mathrm{OL}$ & Downloaded & https://earthexplorer.usgs.gov \\
\hline Sentinel-2 & Downloaded & https://scihub.copernicus.eu/ \\
\hline $\begin{array}{l}\text { Aster GDEM (Digital Elevation } \\
\text { Model - DEM) }\end{array}$ & Downloaded & https://earthexplorer.usgs.gov \\
\hline Rainfall & Downloaded & https://www.chc.ucsb.edu/data/chirps \\
\hline Roads & Downloaded & http://download.geofabrik.de/ \\
\hline Land cover & Derived & from Sentinel-2 \\
\hline Slope angle & Derived & from ASTER DEM (30 m) \\
\hline Aspect & Derived & from ASTER DEM (30 m) \\
\hline River network & Derived & from ASTER DEM (30 m) \\
\hline Lithology & $\begin{array}{l}\text { Digitized from 1:100,000 } \\
\text { geological map }\end{array}$ & $\begin{array}{l}\text { Basic geological map of Serbia 1:100 } 000 \\
\text { (Gornji Milanovac sheet L 34-137) }\end{array}$ \\
\hline Pedology & $\begin{array}{l}\text { Digitized from 1:50,000 } \\
\text { pedology map }\end{array}$ & $\begin{array}{c}\text { Pedology map of Serbia 1:50 } 000 \text { (Valjevo } 4 \\
\text { sheet) }\end{array}$ \\
\hline Landslide reference locations & Provided from authors & $\begin{array}{l}\text { Previous studies (Milošević, 2006) and mu- } \\
\text { nicipality reports }\end{array}$ \\
\hline
\end{tabular}


The aspect is related to sunlight, winds, and rainfall which may control the occurrence of landslides. Winds and rainfall increase landscape instability, while the sunlight increases evaporation which causes less vegetation and increases soil erosion (Suzen and Doyuran, 2004).

The thematic layers of distance to drainage network and roads were calculated by using the Euclidean distance tool of ArcGIS Pro 2.5. A Sentinel-2 image with $10 \mathrm{~m}$ spatial resolution acquired on 12/06/2019 was also used to generate the land cover map after radiometric and atmospheric corrections. The land cover map was produced by supervised Maximum Likelihood Classification of satellite data using ArcGIS 10.4 software and classified into 3 classes: forest, cultivated and built-up areas. This method was used since there is a need for larger-scale land cover mapping. The existing data such as CORINE land cover dataset at a scale of 1:100.000 is often not detailed enough for many national and regional applications.

Data limitations are related to the absence of a meteorological station in the Ljig municipality. Hence, the annual average rainfall was obtained from the inverse distance weight (IDW) interpolation of data from Climate Hazards Group InfraRed Precipitation with Station data (CHIRPS). The CHIRPS is a high-resolution rainfall product with quasi-global coverage. Spanning $50^{\circ} \mathrm{S}-50^{\circ} \mathrm{N}$ (and all longitudes) and ranging from 1981 to near-present, CHIRPS incorporates in-house climatology, CHPclim, $0.05^{\circ}$ resolution satellite imagery, and in-situ station data to create gridded rainfall time series for a 35+year period (Saeidizand, et al., 2017). Dinku et al. (2018) evaluated CHIRPS rainfall data. The evaluations were done by comparing CHIRPS with reference rain-gauge data as well as with two similar satellite rainfall products (ARC2 and TAMSAT). The CHIRPS products performed significantly better than ARC2 and TAMSAT with lower random errors. While CHIRPS often under/overestimates daily precipitation and has limitations for local landslide-related studies, it is often the best available data for studies on a regional scale, if rain gauge data is not available (Hölbling et al., 2020). Therefore, the CHIRPS product has been the most suitable rainfall data alternative for the study area.

Generally, a full landslide inventory covering the study area is desirable which is by far the most basic requirement for landslide susceptibility mapping. Unfortunately, most places in the world, including Serbia, lack the historical database of landslide inventory. This includes some obvious limits due to the lack of some fundamental information such

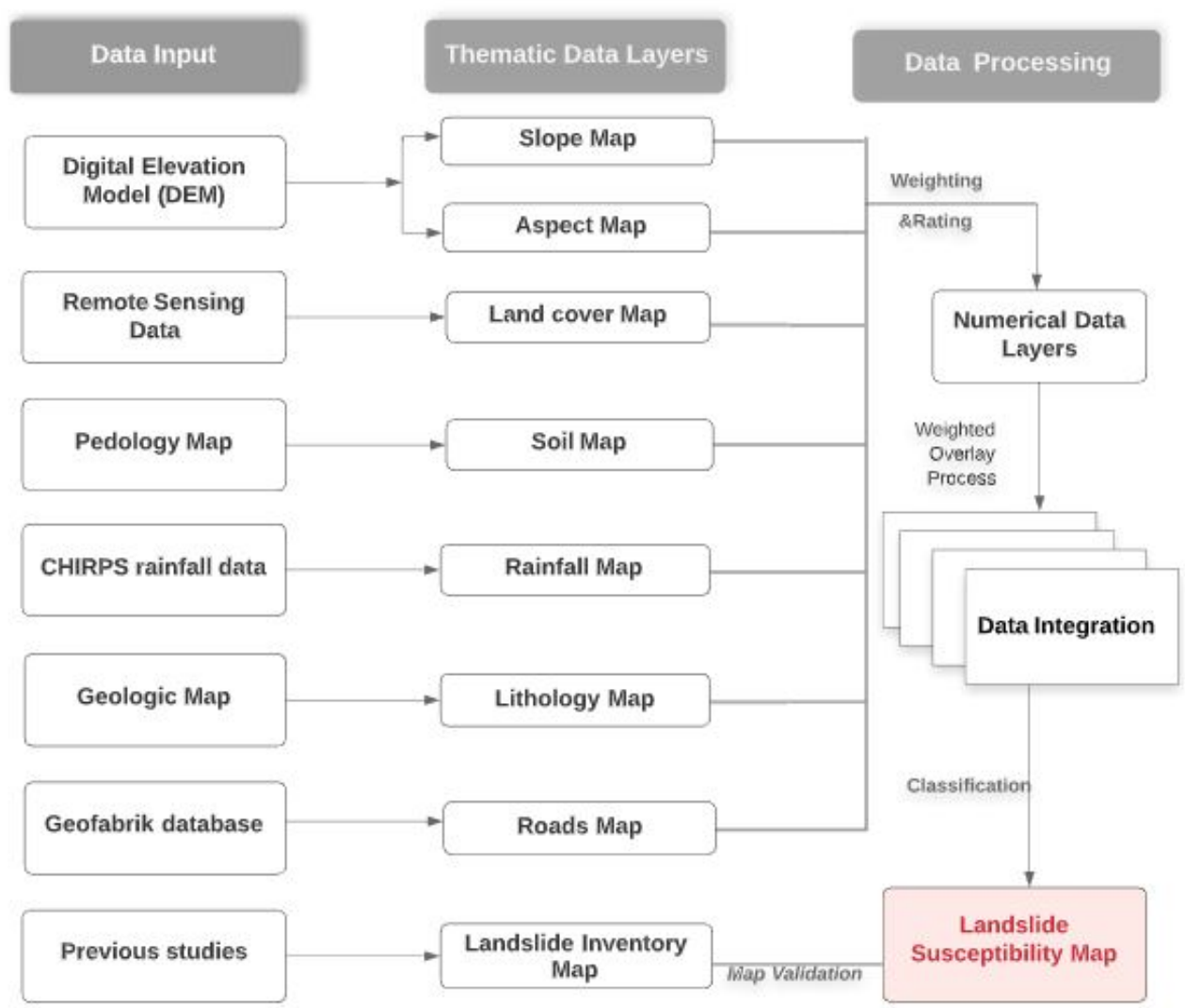

Figure 2. Visualization of GIS model methodology used for landslide susceptibility mapping 
as the landslide occurrences for the whole study area. Therefore, landslide inventory is collected from previous studies. A qualitative heuristic approach is used in this study, which is an optimal approach to map the landslide susceptibility, especially in the absence of landslide inventory data.

\subsection{Methods}

A GIS method based on the collection and analysis of all the factors related to landslides was used to develop a landslide susceptibility map (LSM) of the Ljig municipality. This method involves six steps: I) selecting the relevant factors, II) database construction, III) data layers generation, IV) data preparing, V) numerical ranking of each factor and VI) validation of the landslides model (Sarkar and Kanungo, 2004). Eight conditioning factors affecting the occurrence of landslides were determined for LSM based on the literature review and landslide inventory map of Serbia (GeoSrbija - National Spatial Data Infrastructure). The methodology adopted for this study is illustrated in Fig. 2. All the data were collected or created in a digital raster data format and processed to prepare the different thematic layers. The thematic data were then processed and analyzed to derive the input parameters for the AHP and the weighted overlay method.

The different classes of thematic layers were assigned rating values corresponding to their relative contribution to landslide occurrence (Awawdeh et al., 2018). Previous studies provided important information for weighting and rating the parameters. Rating values were derived through the AHP method. AHP provides objective mathematics to process the subjective and personal preferences of an individual or a group in making a decision (Saaty, 2001). This method provides an opportunity to determine the importance of each criterion (by calculating criteria weights and creating a hierarchy), meaning that the weights will determine the effect of particular criteria in the overall assessment (Božić et al., 2018). The AHP method was used to find the relative weight and priority of individual factors and sub-factors that foster the occurrence of landslides in the Ljig municipality. The multi-criteria assessment based AHP is a decision-making tool to deal with complex and multi-attribute problems and was first developed by Saaty (Gudiyangada Nachappa et al., 2020). It helps decision-makers to discover the best suits of their objective and their understanding of the problem (Jazouli et al., 2019). In this study, the weight of the criteria is based on the expert's opinion, literature and landslides occurrences in Serbia.
After the landslide susceptibility (LS) identification, the accuracy of LS was evaluated by comparing the landslide locations and the LSM. Accordingly, the final LSM was validated by analyzing known landslides within each of the various categories of the landslide susceptibility map.

The landslides are complicated consequence of many terrain characteristics in a particular area such as geological structure, slopes, landforms, hydrology as well as meteorological conditions (He et al., 2019). The impact of lithology on landslides appearance is reflected in the differential between lithology and structure in an area and their highly impact on the strength as well as other properties of rocks and soils such as permeability, porosity, abrasive resistance, etc. (Georgios Stavropolou and Lekkas, 2019; Champati Ray et al., 2007). The topsoil cover on the downhill increases landslide susceptibility, especially when the soil retains water (Wati, 2010). According to Rozos et al. (1988) in many cases heavy rainfall triggers landslides. Thus, the landslide susceptibility was assessed using eight affecting factors (i.e., lithology, distance from roads, distance from river network, slope, aspect, land cover, annual rainfall and pedology). The weight of each factor was determined using the AHP method. All thematic layers were combined using the weight index overlay method to derive the landslide susceptibility map.

The landslide susceptibility maps can be built using the weighted overlay method (WOM), a method of modeling suitability available with Spatial Analyst toolset in Arc GIS (Shit et al., 2016; Intarawichian and Dasananda, 2010)

In this study an overlay of raster layers was done to produce a susceptibility map. According to Intarawichian and Dasananda, 2010, reclassification of all raster layers was made and weighted due to their AHP significance. For this calculation, the following Equation (1) was used:

$$
s=(\Sigma W i s i j) /\left(\sum W i\right)
$$

where,

Wi - the weight of $i$-th factor map

Sij - the i-th subclass weight of $j$-th factor map

$S$ - the spatial unit value of the output map

As a result of the explained process, the landslide susceptibility map was made. Raster calculations were accomplished on the rasterized layers of the eight affecting factors to estimate the overall landslide susceptibility. The results of the application of each model are described in the following section. For the application of the WOM, numerical values were assigned to each of the five susceptibility classes per factor 
as follows: Very low $=1$, Low $=2$, Moderate $=3$, High $=4$, Very High $=5$ (Shit et al., 2016).

\section{Results}

In this study, AHP was used as a multicriteria evaluation approach to identify the potential landslide occurrences in the Ljig municipality. Eight landslide conditioning factors i.e. slope, aspect, pedology, lithology, land cover, rainfall, distance to river network and distance to roads, were employed for susceptibility analysis.

\subsection{Geological factors}

Lithology always has a fundamental role in landslide evolution and landslide occurrences (Sarkar and Kanungo, 2004). There are eighteen lithology groups in the study area (Fig. 3). The most dominant lithology classes are flysch, sands and alluvium and they cover $34.8 \%, 18 \%$ and $15 \%$ of the study area, respectively. Each formation was rated according to its influence in developing landslides. According to expert's opinion, three units are the most important for the landslide events: flysch, clay and conglomerates. Therefore, the highest rating values were assigned to these three lithology groups. The highest rating values ( 4 and 5) cover $71 \%$ of the study area. A majority of the recorded landslide events happened in the areas with high rating values.

Unbound sediments are most prevalent in the Ljig River valley and north of the Kacher River, in the form of gravels, sands and clays. In the conglomerate group, breccias, tuffs and sandstones are many different formations, which are not

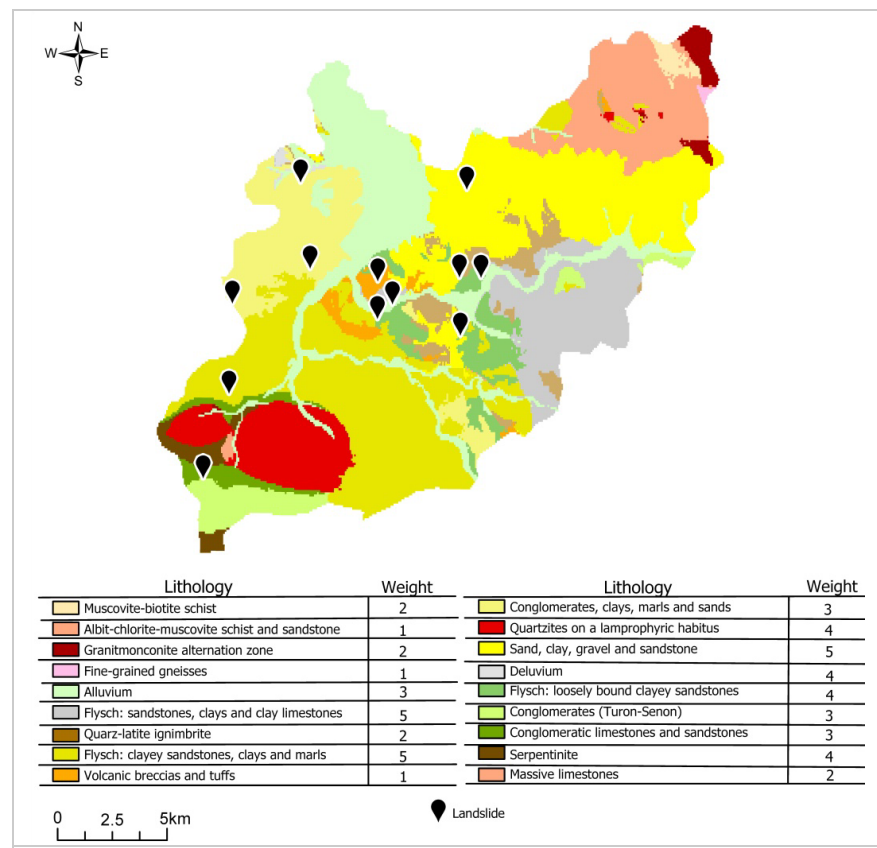

Figure 3. Lithology map especially territorially grouped ones, especially in the Kacher Valley. Flysch is a rock complex that is heavily represented in the municipality of Ljig. It extends west of the Bolshevik junction, in a wide band north and to the east of the Slavkovica volcano, and to the east of the Bolkovo Cave, the most widespread flysch is predominantly composed of sandstone. Compact magmatic rocks occur west of Slavkovica (Milivojević and Ćalić, 2006).

\subsection{Slope}

The slope represents the steepness of the terrain and has an influence on the occurrence of landslides and their development. The slopes of the area range from $0^{\circ}$ to $56^{\circ}$, and were conveniently divided into seven classes (Fig. 4). The highest slopes are found close to the highway and in the southern part of the municipality. The largest area was characterized by the $0-5^{\circ}(31.83 \%)$ and $10-15^{\circ}(23.92 \%)$ slope classes. The slope between $15^{\circ}-35^{\circ}$ is most susceptible to landslide events (Gökceoglu and Aksoy, 1996). These classes are rated with the highest weight and cover $20.2 \%$ of the study area. More than $60 \%$ of landslide events occurred in class III $\left(15-20^{\circ}\right)$, whereas the least landslide events (8.3\%) occurred in class I and class VII $\left(0-15\right.$ and $\left.\geq 35^{\circ}\right)$.

\subsection{Aspect}

Exposition is an indirect factor that affects slope instability (Sarkar and Kanungo, 2004). In the study area the slopes are mostly positioned in the NE-SW direction (Fig. 5). By evaluating the statistical distribution of aspects in areas affected by landslides, the resulting map has revealed that slopes

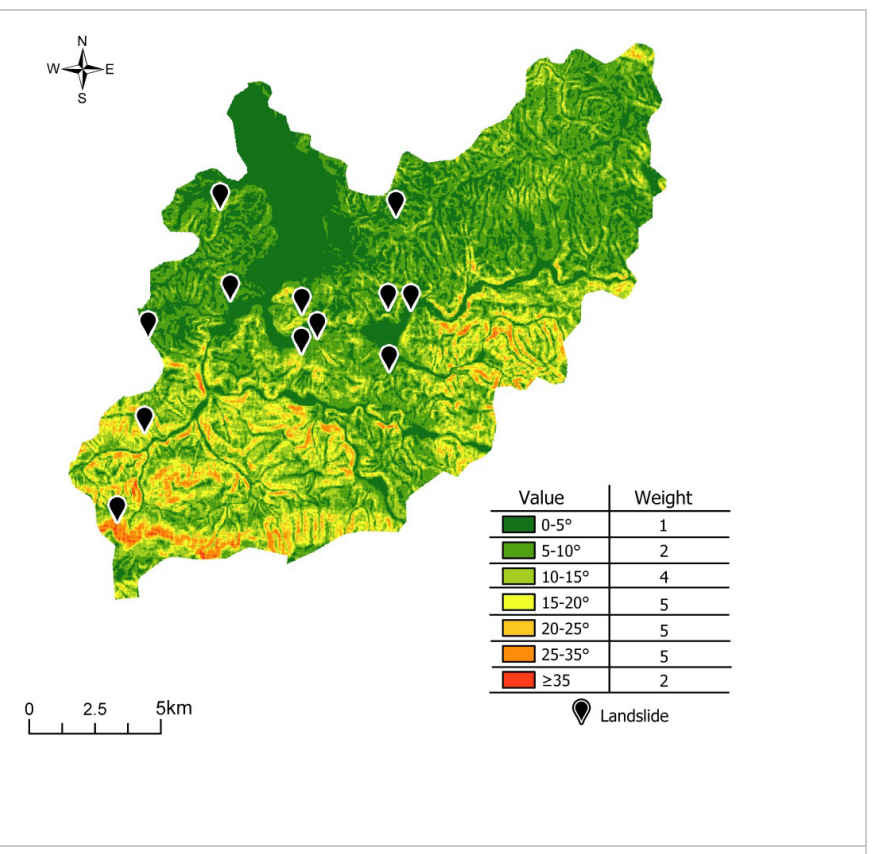

Figure 4. Slope map 
with N-NW direction, where the snow cover lasts longer, are more likely to be landslide-prone than slopes with the S orientation. This happens because slopes on south (on the northern hemisphere) have more sun thus there is less evaporation comparing to northern slopes. Therefore, the slopes with N-NW and NE direction are rated with a high rating value 4 . The expositions with the high rating value occupy the maximum area (41.3\%), whereas the lower values $(3,2,1)$ occupy the following areas: $25.8 \%, 34.7 \%$ and $0.2 \%$, respectively.

\subsection{Pedological factors}

The different soil textures were rated in terms of their potential contribution to landslide occurrence. The study area is dominated by two soil types: gray-brown acid soil on sandstone $(40.4 \%)$ and skeletoidal black soil on serpentine rock (24.2\%). The gray-brown acid soil on sandstone is found mostly in the northern and western parts of the area (Fig. 5). The remaining are skeletal soils on serpentine rocks (12\%), gray-brown soil on limestone rocks (9.5\%), gray-brown skeletoidal acid soil on granit rock (6\%) and skeleton-stone fragments (5\%). The majority of landslide events (40\%) happened on the gray-brown soil on limestone and the shallow black soil. This is mainly due to the potential of such soil classes to retain water during precipitation leading to a reduction in shear strength.

\subsection{Climatological factors}

The most important triggering factor influencing slope stability is the rainfall. The heavy rainfall in the years 2006 and
2014 initiated landslides in the study area. Since then, landslides have become more frequent, especially during the rainy season. The highest rainfall values are observed in the southwestern part of the study area and the lowest values in the northern one (Fig. 7). The statistical analysis of the data showed that the frequency of landslide events increases with increased precipitation. Therefore, rainfall is an important factor in triggering landslides. As a result, the highest susceptibility levels were assigned to the areas of the highest annual height of rainfall. Areas with the highest annual rainfall cover $22 \%$ of the area.

\subsection{Land Cover}

It can be observed that the landslides occur in places with a pronounced anthropogenic factor, i.e. on arable land (Fig. 8). In the areas with dense vegetation, the roots are important for making the slope more stable and less prone to slipping (Nohani et al., 2018). The rating values ranged from 1 for forest to 5 for cultivated/planted areas. Forests, cultivated land and built-up areas cover 51\%, $44 \%$ and $5 \%$ of the study area, respectively. The vast majority of landslides events (75\%) are located in cultivated areas. This indicates that the modification of natural conditions by human activities such as forest harvesting could have a considerable effect on landslide activity in the study area.

\subsection{Distance from roads}

Nohani et al. (2019) under explanation about 'distance from road' as factor for landslide formation, are citing Tuan and Dan (2012) who confirmed the dependence of landslides on

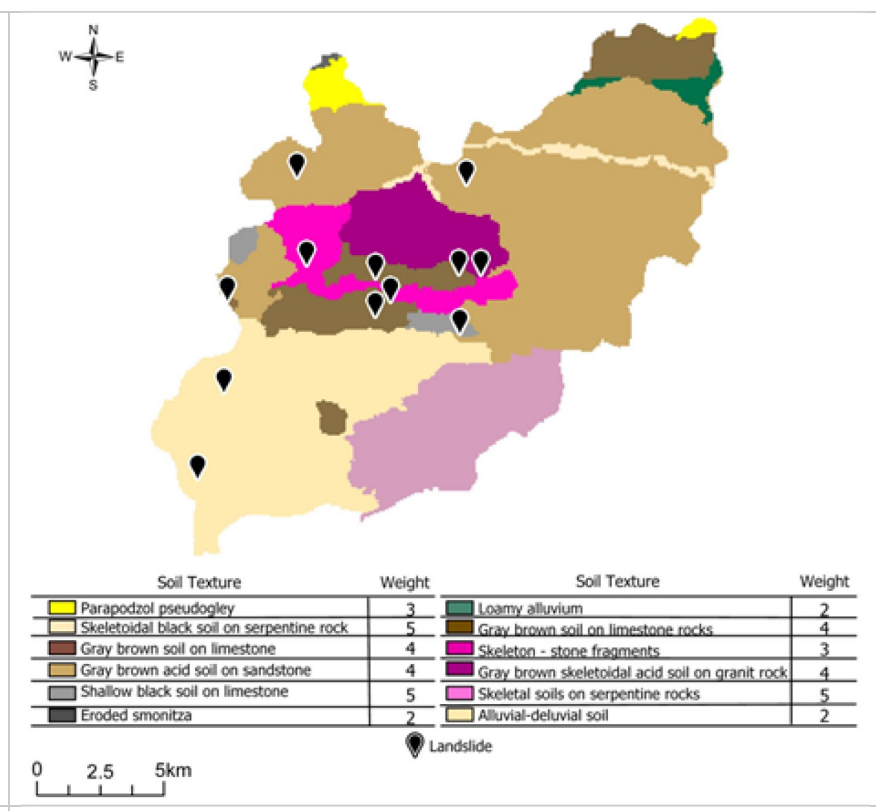

Figure 6. Pedology map
Figure 5. Aspect map

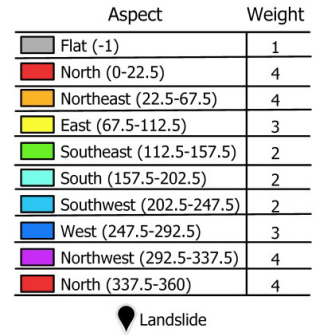

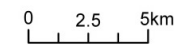

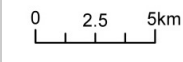


the proximity of roads. They said that "by cutting the slope hills for construction of roads in the slopes more than 10 degrees, discontinuity is made in the soil and rock. Accordingly, the area can be prone to landslides" (Nohani et al., 2019, p. 5). In the area under study the maximum number of landslide events (50\%) occurred within a distance of approximately 0 to $100 \mathrm{~m}$ from any given road (Fig. 9). This may be because the road network can affect slope stability in negative way, eliminating "natural support for the upper part of the slope through undercutting the base of the slope during

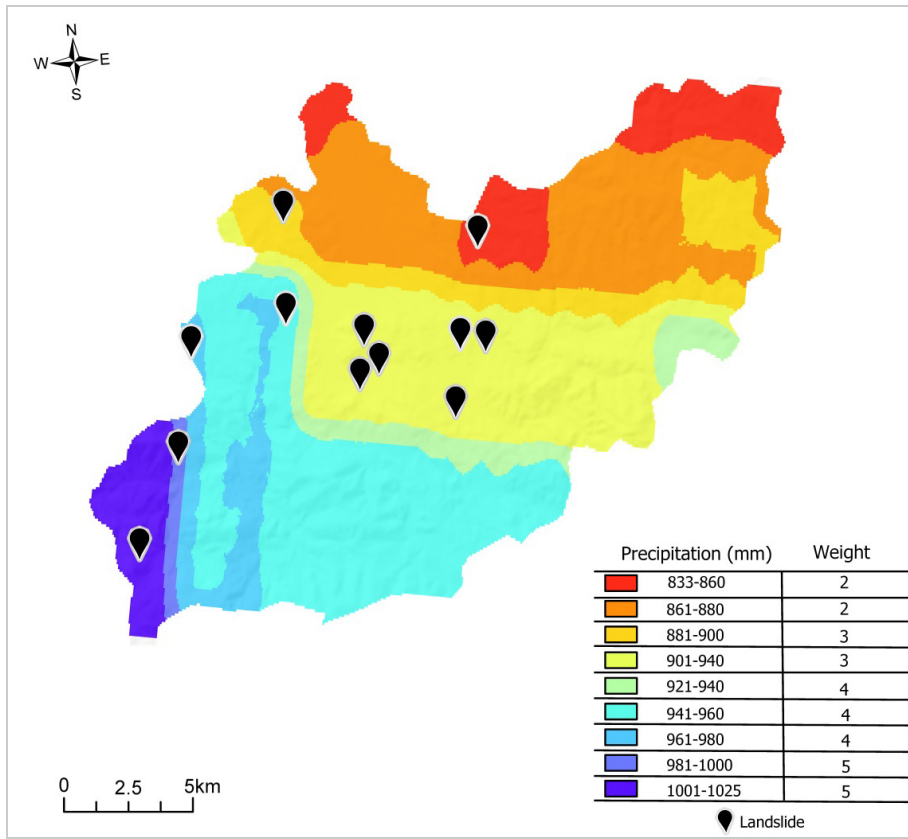

Figure 7. Rainfall map

Figure 9. Distance from roads map

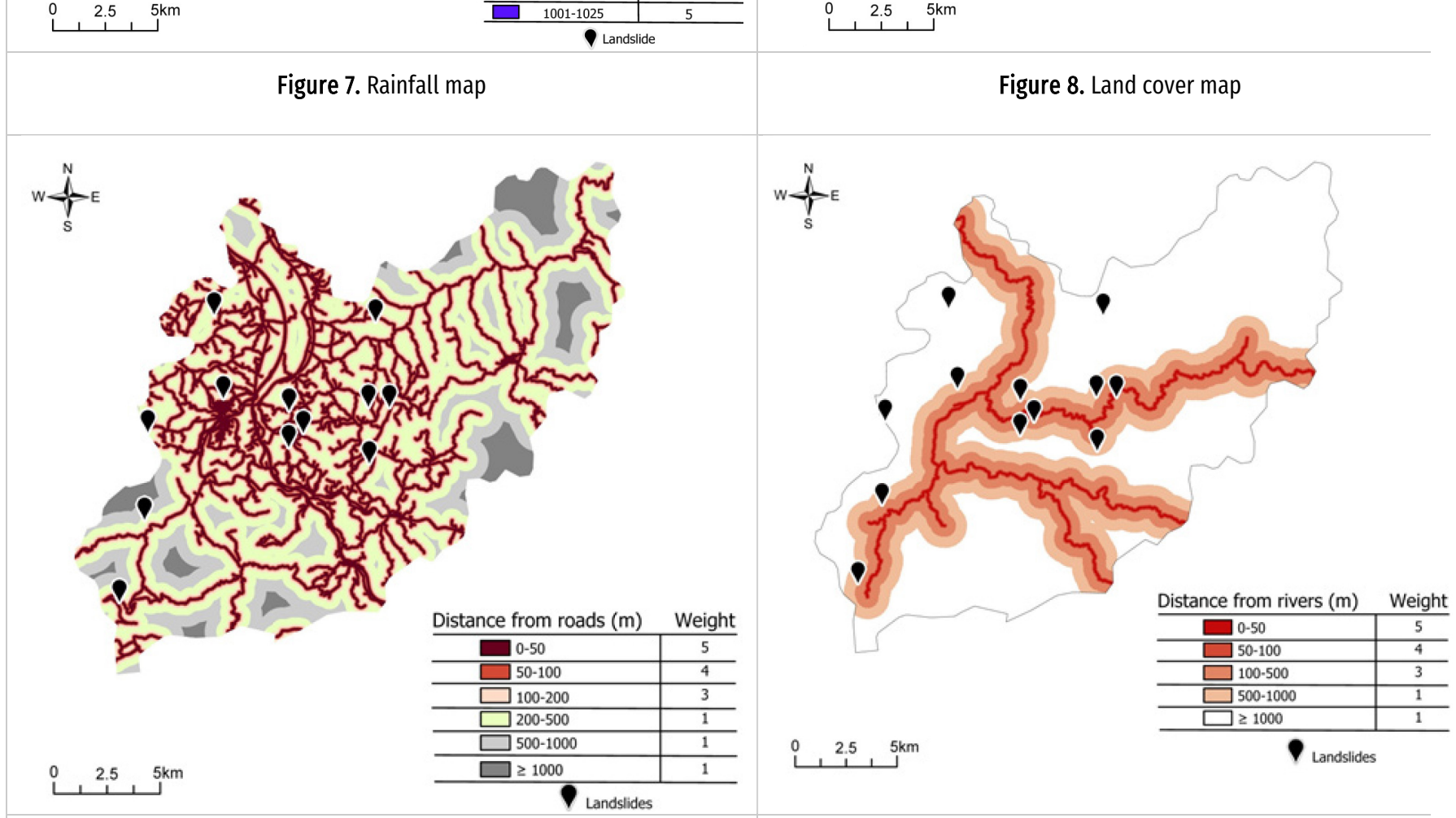

its construction and by adding extra weight on them" (Skilodimou et al., 2018, p. 14). Further away the frequency of landslide occurrences gradually decreases. Accordingly, a medium susceptibility level was given to the buffer up to a distance of $200 \mathrm{~m}$ from the road network while the low susceptibility level was assigned to distances beyond $500 \mathrm{~m}$.

\subsection{Distance from rivers}

The water of rivers is considered as one of the main sources of soil moisture. Pham et al. (2018) stated that $65 \%$ of landslides occurred close to rivers $(0-50 \mathrm{~m})$. According to this

Figure 10. Distance from rivers map 
statement, rivers represent very dominant factor in LSM. This factor was extracted through Euclidean Distance tool in ArcGIS Pro 2.0 software and classified into five classes as following (1) 0-50, (2) 50-100, (3) 100-500, (4) 500-1000, and (5) $>3000 \mathrm{~m}$ (Fig. 10). He et al. (2019) determined characteristic factors for landslide formation and one of them is 'distance from rivers' where they revealed that "landslides are active in regions where scouring intensity is enhanced as a result of hydrostatic action or human disturbance" (p. 15). In the Ljig municipality in areas distanced 0-50 $\mathrm{m}$ from the river, there is a high potential of landslide occurence.

\subsection{Land susceptibility map}

After the assessment of all factors independently, weighted overlay analysis (WOA) was performed. For WOA, a five-step landslide susceptibility scale was used: very low, low, medium, high and very high susceptibility. AHP method was used to determine the weight for each factor (Table 2).

Table 2. Factors weight in WOA

\begin{tabular}{cc}
\hline Factor & Weight (\%) \\
\hline Geology & 21 \\
Pedology & 10 \\
Slope & 15 \\
Aspect & 3 \\
Rainfall & 14 \\
Land cover & 17
\end{tabular}

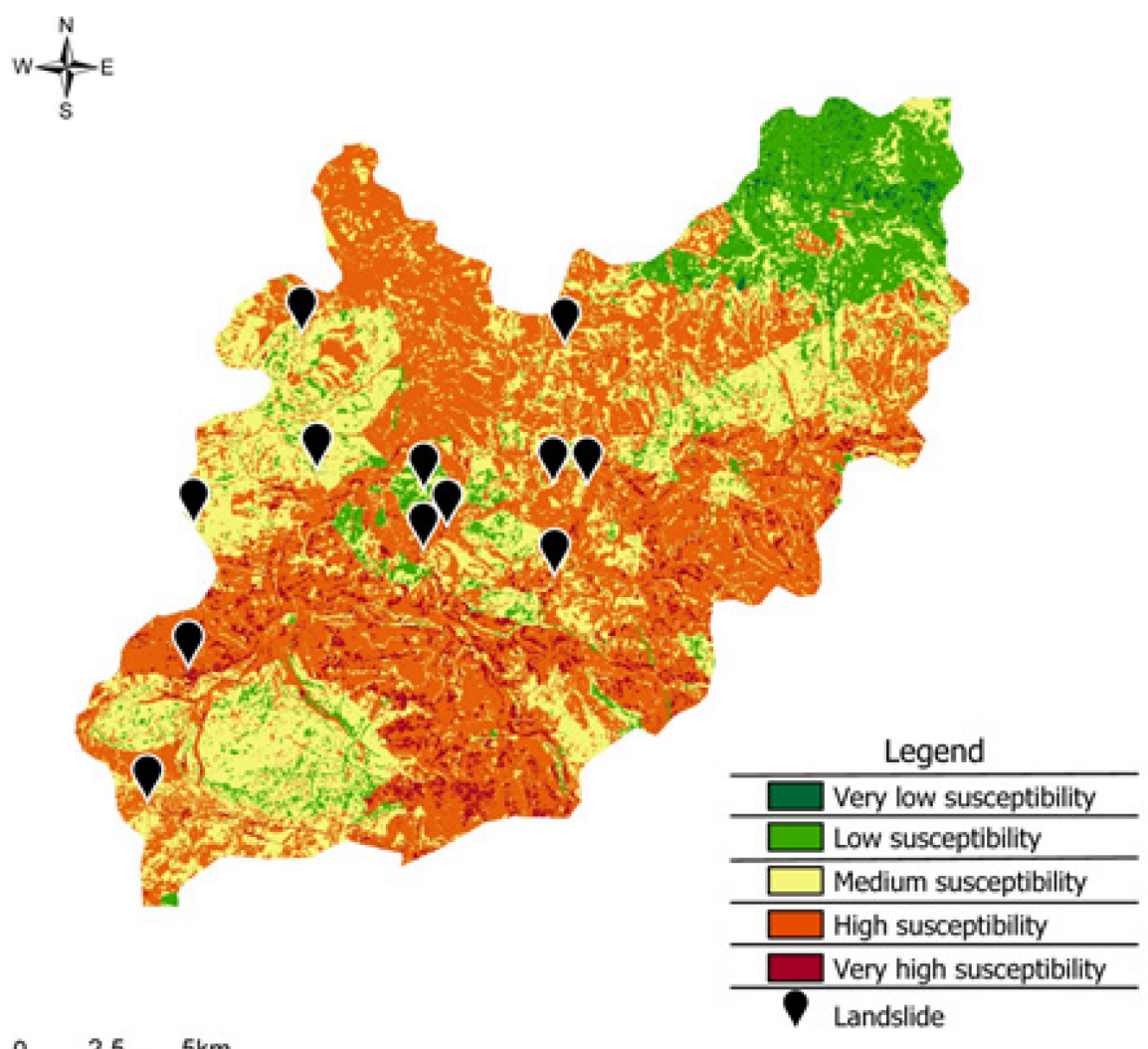

Figure 11. Landslide susceptibility map

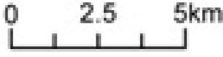

\begin{tabular}{ll}
\hline Distance from roads & 10 \\
Distance from rivers & 10 \\
\hline
\end{tabular}

Geology with a weight of $21 \%$ stood out as the main factor for landslide risk assessment. The second most important factor is land cover, which has proven to be extremely important for landslide risk assessment in the field (existing landslides) and in the literature. It is worth mentioning that aspect is the least important factor at the locations of existing landslides, not only in the municipality of Ljig but also in other municipalities in Serbia. This is mainly because it is extremely variable, and thus, aspect cannot be considered as a key factor for risk assessment, although it is often mentioned in literature.

Based on the map of landslide susceptibility, areas with varying levels of risk were inventoried. It can be concluded that a total of $24 \%$ of the area is not susceptible (very low and low susceptibility) and $55.4 \%$ of the area is susceptible (high and very high susceptibility) to a landslide occurrence (Fig. 11). The remaining $20.6 \%$ of the area falls within the area of moderate susceptibility. The spatial distribution of these shares by susceptibility categories is primarily due to the geological structure of the area, and the morphometric terrain parameters. The areas of very high susceptibility are 
mainly found in southern and central parts of the municipality. Very low and low susceptibility areas are located in northern parts of the municipality.

\section{Discussion}

The creation of LSM and information that it gives can contribute to the development of hazard strategies and beside that detect potential locations for landslide formation and in that way help in risk mitigation (Nohani et al., 2019). A landslide susceptibility map is a useful tool in natural and urban planning, especially for the definition of the land use zones and for the design of future construction projects. The AHP model is usually based on a rating system provided by expert opinion. Expert opinion is very convenient in resolving complex problems like landslides. However, to some extent, opinions may change for every individual expert, and thus may be subjected to cognitive limitations with uncertainty and subjectivity (Jazouli et al., 2019).

When speaking about landslides and man activity the mutual influence is obvious. The houses and buildings that are built on unstable terrains are very likely to have great consequences through infrastructure damage and destruction. Landslides can harm large areas of settlements as well as act locally which means that some part of the certain infrastructure is destroyed. This property also includes water reservoirs, electricity systems, roads, etc. The secondary affected sectors are tourism, industry, transport, and environment that can have long-term results. Since in Serbia there are no exact and clear land-use policies, this problem becomes bigger. Building permits for some objects can be questioned. The quality of the infrastructures should be examined because communities often are not able or prepared to act quickly and prevent damage. On the other hand, climate conditions are also one of the main factors when it comes to the landslide formation. The frequency and intensity of rainfall events can induce sudden landslides and contribute to greater destruction. For the reasons stated above, during the 2014 extreme rainfall, when landslides in the Republic of Serbia and the municipality of Ljig were triggered, traffic infrastructure and residential buildings were mostly affected. All existing landslides considered in this study have just been recorded because they endangered the infrastructure and suprastructure of the municipality.

The data obtained indicate that the central and southern parts of the study area are the most susceptible. The central and southern parts of the area include 15 settlements with $60 \%$ of the total population of the Ljig municipality. Adding the dense road network to this, it can be concluded that damage from the activation of landslides would be extensive.

The results show that as much as $44.7 \mathrm{~km}$ of the municipality's transport network is in the area of the highest risk of landslides and as much as $285.3 \mathrm{~km}$ is at high risk of landslides. It is also interesting that the highway itself is partly in the area of extremely high risk, but precisely because of the extremely risky terrain for the construction of infrastructure, the highway mostly goes underground (tunnel) through the high-risk area.

Due to the very high percentage of the threatened territory (54\%), additional factors should be measured in the field to further increase the reliability of the results. Those factors should be implemented in future studies. Finally, the model would be complemented with in-situ terrain observations.

In addition to defining the criteria themselves, locations of existing landslides in the municipality of Ljig were used to validate the data. The assessment results show that almost $83 \%$ of landslides are distributed in the very high susceptibility (VHS) and high susceptibility (HS) zones, while 17\% of landsides occurred in the moderate susceptibility (MS) zones. In low susceptibility (LS) and very low susceptibility (VLS) zones there are no recorded landslide events, therefore it can be concluded that this model provides reliable results.

This research may provide a basis for further improvement of the methodology. Ideally, planning and construction efforts, as well as the environmental policy within the territory of the municipality of Ljig, would consider landslide susceptibility zones as an important source for future regional planning and development efforts, as well as for risk management.

\section{Conclusion}

In the determined LS and MS zones, it is possible to plan and construct buildings along with any economic activity. Instead, in the HS and VHS zones, extra consideration should be given in planning for any activity, including building construction. Consequently, the more hazardous the zone is, the more specific the wariness on planning is needed. Human activities such as road cuts coupled with natural factors such as lithology and slope made most parts of the study area prone to landslides. Unfavorable rock strata such as flysch, loosely bound clayey sandstone and clays are considered the main contributing factors for landslides. The HS zone should be entirely avoided for settlement or other developmental purposes. If unavoidable circumstances compel the execution of road cutting and urban projects, caution should be 
taken in consultation with geological experts. The MS zone comprises areas that have intense road cuts with low drainage density and relatively weak-to-moderately strong rocks. Although this zone involves areas that are stable in the present condition, future land use activity must be duly planned to maintain its current status. The low susceptibility zone is stable. In rare sites, some slope instability was observed in this zone due to the road cutting in moderately fractured rock. The VLS zone is very stable, and it generally comprises areas covered by dense forest and strong rock structure, mostly located far from human activity. The validation of the model verified that the selected causative factors are highly relevant and that the model performs properly. However, further data collection on landslides may change the results of model validation.

The final susceptibility map can be considered as a base map for landslide hazard evaluation when intending to avoid or reduce future hazard's impacts and improve decisionmaking prior to any development in this municipality. The result can be useful for explaining the conditioning factors for triggering landslides, thereby, supporting the efforts to mitigate future landslide hazards in the study area. As previously mentioned, a landslide is an underestimated, in turn, less studied subject in Serbia. This study may serve as an initiative and suggests that more efforts should be made to investigate the landslide hazard in other basins in central Serbia. Besides, landslide susceptibility mapping is an important step prior to landslide assessment planning, management and disaster mitigation. Identification and detailed assessment of this underestimated hazard are needed in effective landslide hazard reduction through disaster mitigation planning and development strategies.

\section{ORCID iDs}

Dajana Tešić (D) https://orcid.org/0000-0002-3948-3420 Jasmina Đorđević (D) https://orcid.org/0000-0002-1990-4398 Daniel Hobling (D) https://orcid.org/0000-0001-9282-8072 Tijana Đorđević (D) https://orcid.org/0000-0002-4701-7999 Dragana Blagojević (D) https://orcid.org/0000-0002-6812-9113 Nemanja Tomić (D) https://orcid.org/0000-0001-6074-3912 Aco Lukić (D) https://orcid.org/0000-0001-7531-6796

\section{References}

Abrams, M. (2016). ASTER global DEM version 3, and new ASTER water body dataset. International Archives of the Photogrammetry, Remote Sensing and Spatial Information Sciences, 107-110. DOI: 10.5194/isprs-archives-XLI-B4107-2016

Ali, S., Biermanns, P., Haider, R., \& Reicherter, K. (2019).
Landslide susceptibility mapping by using a geographic information system (GIS) along the China-Pakistan Economic Corridor (Karakoram Highway), Pakistan. Natural Hazards and Earth System Sciences, vol. 19, 999-1022. DOI: 10.5194/nhess-19-999-2019

Awawdeh, M., ElMughrabi, M., \& Atallah, M. (2018). Landslide susceptibility mapping using GIS and weighted overlay method: a case study from North Jordan. Environmental Earth Sciences, 77. DOI: 10.1007/s12665-018-7910-8

Bell, F.G. (2007). Engineering Geology. Elsevier, Oxford, UK, pp. 581

Božić, S., Vujičić, D.M., Kennell, J., Besermenji, S., \& Solarević, M. (2018). Sun, Sea and Shrines: Application of Analytic Hierarchy Process (AHP) to Assess the Attractiveness of Six Cultural Heritage Sites in Phuket (Thailand). Geographica Pannonica, vol. 22, iss. 2, pp. 121-138. DOI: 10.5937/22-16983

Carrara, A., Cardinal, M., Guzzetti, F., \& Reichenbach, P. (1995). GIS technology in mapping landslide hazard. Geographical Information Systems in Assessing Natural Hazards. Kluwer Academic Publishers, Dordrecht, The Netherlands, pp. 135-175

Champati Ray, P. K., Dimri, S., Lakhera, R. C., \& Sati, S. (2007). Fuzzy-Based Method for Landslide Hazard Assessment in Active Seismic Zone of Himalaya. Landslides, 4, 101111. DOI: 10.1007/s10346-006-0068-6

Cruden, D.M., \& Varnes, D.J. (1996). Landslide types and processes. In: Turner AK, Schuster RL (eds) Landslides investigation and mitigation. Transportation research board, US National Research Council. Special Report 247, Washington, DC, Chapter 3, pp. 36-75.

Dinku, T., Funk, C., Peterson, P., Maidment, R., Tadesse, T., Gadain, H., \& Ceccato, P. (2018). Validation of the CHIRPS satellite rainfall estimates over eastern Africa. Quarterly Journal of the Royal Meteorological Society, 144 (S1).pp. 292-312. DOI: 10.1002/qj.3244

Đorđević, J. (2006). Evaluation of a natural complex: Municipality of Ljig case study. Journal of the Geographical Institute "Jovan Cvijic" SASA, 55. (In Serbian)

Fell, R., Coromina, J., Bonnard, C., Cascini, L., Leroi, E., \& Savage, W. (2008). Guidelines for landslide susceptibility, hazard and risk zoning for land use planning. Engineering Geology, vol. 102, pp. 83-84. DOI: 10.1016/j.enggeo.2008.03.022

Galli, M., Ardizzone, F., Cardinali, M., Guzzetti, F., \& Reichenbach, P. (2008).Comparing landslide inventory maps. Geomorphology, vol. 94, iss. 3-4, pp. 268-289, DOI: 10.1016/j.geomorph.2006.09.023 
Georgios, N., Stavropolou, M., Lekkas E. (2019). Landslide Susceptibility Estimation Using GIS. Evritania Prefecture: A Case Study in Greece. Journal of Geoscience and Environment Protection.

Geosrbija - National Spatial Data Infastructure: https://a3.geosrbija.rs/

Gökceoglu, C. \& Aksoy, H., (1996). Landslide susceptibility mapping of the slopes in the residual soils of the Mengen region (Turkey) by deterministic stability analyses and image processing techniques. Engineering Gelogy, 44 (4): 147-161. DOI: 10.1016/S00137952(97)81260-4

Gudiyangada Nachappa, T,. Kienberger , S., Meena, S,R., Hölbling, D., \& Blaschke, T. (2020). Comparison and validation of per-pixel and object-based approaches for landslide susceptibility mapping. Geomatics, Natural Hazards and Risk, 11:1, 572-600. DOI: 10.1080/19475705.2020.1736190

He, H., Hu, D., Sun, Q., Zhu, L., \& Liu, Y. (2019). A Landslide Susceptibility Assessment Method Based on GIS Technology and an AHP-Weighted Information Content Method: A Case Study of Southern Anhui, China. ISPRS international journal of geo-information, 8. DOI: 10.3390/ijgi8060266

Hölbling, D., Abad, L., Dabiri, Z., Prasicek, G., Tsai, T.-T., \& Argentin, A.-L. (2020). Mapping and Analyzing the Evolution of the Butangbunasi Landslide Using Landsat Time Series with Respect to Heavy Rainfall Events during Typhoons. Applied Sciences, 10(2), 630. DOI: 10.3390/app10020630

Intarawichian, N., \& Dasananda, S. (2010). Analytical Hierarchy Process for landslide susceptibility mapping in lower Mae Chem watershed, Northern Thailand. Suranaree Journal of Science and Technology, 17(3):277-292.

Jazouli, A., Barakat, A., \& Khellouk, R. (2019). GIS-multicriteria evaluation using AHP for landslide susceptibility mapping in Oum Er Rbia high basin (Morocco). Geoenviromental Disasters, 6:3. DOI: 10.1186/s40677-019-01197

Lee, E.M., \& Jones D.K.C. (2004). Landslide risk assessment. Thomas Telford Publishing, London, UK, pp. 454.

Marjanović, M. (2013). Advanced method for landslide assessment using GIS (Doctoral dissertation). Palacky Univeristy, Olomuc, Faculty of Science, Department of Geoinformatics, Olomuc, Czech Republic.

Milivojević, M., \& Ćalić, J. (2006). Basic geological and geomorphological charactericts of Ljig municipality for the needs of spatial planning (Osnovne geološke i geomorgološke odlike prostora opštine Ljig za potrebe prostornog planiranja) (In Serbian). Journal of the Geographical Institute "Jovan Cvijić" SAS, 55. UDC: 911.2:551.4 (497.11)

Milošević, M., Milivojević, M., \& Ćalić, M. (2006). Aktivna klizišta na području opštine Ljig (Active landslides in the municipality of Ljig). (In Serbian). Bulletin of the Serbian Geographical Society, 1, 1. UDC: 551.053 (497.11)

Municipalities and regions of the Republic of Serbia 2018. (2019). Belgrade: Statistical Office of Republic of Serbia. Nohani, E., Moharrami, M., Sharafi, S., Khosravi, K., Pradhan, B., Pham, B., Lee, S., \& Melesse, A. (2019). Landslide Susceptibility Mapping Using Different GIS-Based Bivariate Models. Water, 11. DOI: 10.3390/w11071402

Pellicani, R., Argentiero, I., \& Spilotro, G. (2017). GIS-based predictive models for regional-scale landslide susceptibility assessment and risk mapping along road corridors. Geomatics, Natural Hazards and Risk, 8:2, 1012-1033. DOI: 10.1080/19475705.2017.1292411

Pham, B.T., Tien Bui, D., \& Prakash, I. (2018). Application of Classification and Regression Trees for Spatial Prediction of Rainfall Induced Shallow Landslides in the Uttarakhand Area (India) Using GIS. In Climate Change, Extreme Events and Disaster Risk Reduction; Springer: Berlin/Heidelberg, Germany; pp. 159-170. DOI: 10.1007/978-3-319-56469-2_11

Radanović, M. (2010). Primena metoda evaluacije fizičkogeografskih faktora na primeru opštine Ljig. (Application of evaluation method of physical-geographical factors on the case of Ljig municipality). M.Sc. Thesis. University of Novi Sad, Department for Geography, Tourism and Management, Novi Sad, Serbia.

Rozos, D., Hatzinakos, I. \& Nicolaou N.S. (1988). Landslides inventory and classification of the mountainous road network of the Karditsa county. Bulletin of Geological Society of Greece, 23: 95-109.

Saaty, T.L. (2001). The seven pillars of the analytic hierarchy process. In: Multiple Criteria Decision Making in the New Millennium, 15-37. Berlin, Heidelberg: Springer.

Salvatici, T., Tofani, V., Rossi, G., Ambrosio, M., Tacconi Stefanelli, C., Benedetta Masi, E., Rosi, A., Pazzi, V., Vannocci, P., \& Petrolo, M. (2018). Application of a physically based model to forecast shallow. Natural Hazards and Earth System Sciences, 18, 1919-1935. DOI: 10.5194/nhess-18-1919-2018

Sarkar, S., \& Kanungo, D. (2004). An integrated approach for landslide susceptibility mapping using remote sensing 
and GIS. Photogrammetric Engineering and Remote Sensing, 70(5), 617-625. DOI: 10.14358/PERS.70.5.617

Saeidizand, R., Samaneh, S., Tarnavsky, E., \& Pierleoni, A. (2018). Evaluation of CHIRPS rainfall estimates over Iran. Quarterly Journal of the Royal Meteorological Society, 144 (S1). pp. 282-291. DOI: 10.1002/qj.3342.

Skilodimou, H., Bathrellos, G., Koskeridou, E., Soukis, K., Rozos, D., (2018). Physical and Anthropogenic Factors Related to Landslide Activity in the Northern Peloponnese, Greece. Land 7(3), 85 DOI: doi.org/10.3390/land7030085

Shit, P., Bhunia, G., \& Maiti, R. (2016). Potential landslide susceptibility mapping using weighted overlay model (WOM). Modeling Earth Systems and Environment, vol. 2. DOI: 10.1007/s40808-016-0078-x.

Suzen, M. L., \& Doyuran, V. (2004). Data driven bivariate landslide susceptibility assessment using geographical information systems: a method and application to Asarsuyu catchment, Turkey. Engineering Geology, 71, 303-321. DOI: 10.1016/S0013-7952(03)00143-1

Spatial plan of the municipality of Ljig (2008). Geographical Institute "Jovan Cvijic" of the Serbian Academy of Sciences and Arts. (In Serbian)

Tuan, T., \& Dan, N. (2012). Landslide susceptibility mapping and zoning in the Son La hydropower catchment area using the analytical hierarchy process. International Journal of Earth Sciences, 3, 223-232.

Van Westen, C. J., Castellanos, E. A., \& Sekhar, L. K. (2008). Spatial data for landslide susceptibility, hazards and vulnerability assessment: an overview. Engineering geology, 102(3-4-2017), 112-131. DOI: 10.1016/j.enggeo.2008.03.010

Van Westen, C.J., Rengers, N., \& Soeters, R. (2003). Use of geomorphological information in indirect landslide susceptibility assessment. Natural Hazards, vol. 30, no. 3, p. 399-419. DOI: 10.1023/B:NHAZ.0000007097.42735.9e

Wati, S. (2010). Integrating landslide susceptibility into land capability assessment for spatial planning: a case study in Tawangmangu Sub District, Karanganyar Regency, Indonesia. M.Sc. Thesis. ITC University of Twente Netherlands and GMU Yogyakarta. 